\title{
Diurnal patterns in crude protein and amino acid flow in the duodenum and the influence of time of feeding a protein meal to lactating cows
}

\author{
$M$ Gill 1, P Robinson 2 \\ 'Natural Resources Institute, Chatham Maritime, Chatham, Kent, ME4 4TB, UK; \\ 2Fredericton Research Centre, PO Box 20280, Fredericton, NB, E3B 4Z7, Canada
}

Diurnal patterns in duodenal flow have been observed in sheep fitted with re-entrant cannulae in the duodenum (Harris and Phillipson, 1962, Anim Prod, 4, 97-116; Phillips and Dyck, 1964, Can J Anim Sci, 44, 220-227). The highest flow rate was observed just prior to and for some hours after the morning feed, with a trough in flow observed in the afternoon and evening in sheep offered feed once daily at 09:00 h. Similar patterns have been observed for rumen contractions in young cattle by Thiago, Gill and Dhanoa (1992, $\mathrm{Br} J$ Nutr, 67, 319-336), with muscular activity being highest between 12 to $21 \mathrm{~h}$ after feeding. Thus it was hypothesised that feeding protein during this period of high outflow could increase the proportion escaping digestion in the rumen.

Cows, cannulae and duodenal sampling regime are described by Robinson and Gill (1995, these proceedings). Cr-mordanted lucerne dosed into the rumen at $2 \mathrm{~h}$ intervals was used as the flow marker. The mixed ration consisted of approx. $12 \%$ lucerne, $48 \%$ oat silage and $40 \%$ concentrate. The protein supplement contained a mixture of rapeseed meal, soyabean meal, fishmeal, corn gluten meal and ground barley. This was fed at approximately $15 \%$ of the mixed ration intake at either 08:30 h ('day') or 00:30 h ('night').
The mean concentration of crude protein in duodenal digesta did not differ significantly between treatments $(P>0.1)$, but there was a significant $(P<0.001)$ treatment by time interaction. The variability was greater in the 'day', than the 'night' cows (table). There were also significant $(P<0.05)$ treatment by time interactions for the ratios of aspartate, threonine, glutamate, glycine, valine, isoleucine, leucine, lysine and arginine to the sum of all the amino acids analysed, but not for methionine, cystine, serine, proline, tyrosine, phenylalanine or histidine. The peak ratio for glutamate and leucine was in the late afternoon/early evening, corresponding with a trough for threonine, valine, isoleucine, aspartate, glycine and lysine, particulariy for 'day' cows. As might be expected, the pattern for flows of individual amino acids largely reflected the pattern for flow of crude protein, with the variability again being much less for the 'night' cows (table). Analysis of diaminopimelic acid indicated a higher percentage of dietary protein escaping digestion in the rumen from 'day' cows $(50 \%)$ relative to 'night' cows (39\%), disproving the original hypothesis. However, the results suggest that manipulation of feeding strategies can alter the synchronisation of nutrient absorption and this had a significant $(P<0.05)$ effect on milk fat yield.

\begin{tabular}{ccc}
\hline & 'Day' cows & 'Night' cows \\
\hline $\begin{array}{c}\text { Concentration of protein in duodenal digesta }(g \mathrm{CP} / \mathrm{kg} \mathrm{DM}) \\
\text { Minimum }\end{array}$ & 210 & 232 \\
$\begin{array}{l}\text { Maximum } \\
\text { Mean }\end{array}$ & 320 & 289 \\
$\begin{array}{c}\text { Mlow of protein into the duodenum }(\mathrm{g} C P / h) \\
\text { Minimum }\end{array}$ & 271 & 265 \\
Maximum & 86.3 & \\
Mean & 179.7 & 104.0 \\
& 130.5 & 128.5 \\
\hline
\end{tabular}

